\author{
都市施設の適切な数に関する数理モデル \\ 一政令指定都市の区数に関する分析例一 \\ A MATHEMATICAL MODEL ON THE OPTIMAL NUMBER \\ OF URBAN FACILITIES \\ -Empirical analysis on the number of the wards of \\ the ordinance-designated cities in Japan-
}

\author{
栗田 治* \\ Osamu KURITA
}

\begin{abstract}
A mathematical model on the optimal number of urban facilities is concerned in this paper. The model is to minimize the sum of two types of cost: 1) facilities construction and operation cost and 2) transportation cost from residences to the facilities. The model is formulated under two assumptions: i) the population density is uniform all over the city; ii) each territory of the facility is mutually congruent. One of the main results is as follows: If the construction and running cost of a facility is linear function of the number of allocated users, the optimal rumber of the facilities is proportional to two-thirds power of the population of the city times the cube root of the area of the city. By this result, we can rationally compare the numbers of facilities of cities whose population and area vary. In this paper, the numbers of wards in the ordinance-designated cities in Japan are empirically examined. Moreover, our study clarifies that the average. cost per capita is the decreasing function of the population density of city. According to this result; we can argue how the consolidation of two cities effects on the average cost per capita.
\end{abstract}

Keywords : The number of urban facilities, construction cost, transportation cost, The number of wards of the ordinance-designated cities in Japan 都市施設の数, 建設コスト，移動コスト，日本の政令指定都市の区数

1. はじめに

都市内の施設の多蹇はよく議論の対象となる. 都市甲にはある種 の施設の数が多い. 一方都市乙には少ない, といった具合に. こうし た議論は専ら都市で暮らす人々の直観に基づいてなされ，それを裏 付ける客観的な論理はあまり語られない.よく用いられる客観的な 指標は平均値ぐらいなものであろうか.すなおち住民一人当たりの 施設数，といったものである.これは特に官公庁の 2 次統計資料に多 く見られる指標である.しかし，この平均值による都市比較は，多 くの場合, それほど気の利いたもののようには思えない，何故なら ぼ, 都市の持つ空間的な性質との関係が希薄な数值だからである.

そもそも都市内に同一種の施設を複数個設けるとき，その数はど の様に決定すべきだろうか. 勿論, 施設の数が小さいほど建設・運営 費は低廉ですむ. すなわち施設数は小さい程良い(極論すれば, 施設 を設けないことが最良の解). しかし, 住民は都市平面に分散して住 んでいる. したがって施設の数が有限の場合，住民は移動せねばサー ビスが受けられない、これもまた自明である，移動費用の観点から すると，施設は都市内に遍く存在していることが望ましいのである.

ここで, まず，全ての住民が等しい頻度で利用すべき公共的施設 を想定しよう. 例としては, 区役所, 保健所, 図書館, 広域公園, 公 立小中学校などが考えられる.これら施設の場合, 結局のところ, 前
者の施設建設 - 運営費も, 後者の交通費も, ともに都市住民が負担 せねばならない. ただし，前者は税負担という形でなされ，後者は 移動に関する費用負担という形でなされる.

他方, 施設が営利目的だとしても, 同様の理屈が成り立つ場合が ある：例えばピザの宅配チェーンを想定し， 1 経営者が $n$ 個の店舗を 設けることにしよう。ここ場合, 店舗の建設・運営費と宅配輸送費の 双方を，この経営者が負担せねばならない，

上述の公共施設やチェーン店タイプの営利施設に共通で重要な性 質は, 施設を増やすと移動距離の面で便利になるが, 同時に建設・運 営費が増加してしまうことである. 既存の施設計画論を網羅的に整 理したと思われる研究文献1)2)などを観ても，この性質にはあまり言 及されていない，そこで本研究では，このトレード・オフを前提と し, 費用の負担者(公共施設の場合は住民, 営利施設の場合は経営者) にとって適正な施設数を決定するための巨視的なモデルを提案する.

特に今回は, 本研究のモデルの結果を利用して, 政令指定都市に おける区の数に関する実証分析を行った結果を述べる(4節).

従来, 1 つの施設の適正な規模を決定するための要件に関しては, 潤沢なる分析・議論がなされてきた文献2)。しかし，本研究のような， 施設の数と規模を併せて考慮し，都市の空間的な枠組みとの関係に 着目して位置づける結果は殆どないように見受けられる。 


\section{2. 定式化}

ここでは説明を明解にすべく，公共施設に的を絞った記述を行う. なお，ここでの記号を適宜読み替えることにより，チェーン店型の営 利施設に関するモデルと見做すことも可能である注1).

まず，対象都市の面積を $S\left[\mathrm{~km}^{2}\right]$ とし，住民(すなわち施設利用者) の人口を $P[$ 人] とする．簡単のために都市内で住民が一様に分布する と想定する，一様でない場合は，都市域を人口密度が一様と見做さ れるような部分領域に分割し，領域毎に問題を定式化すればよい.

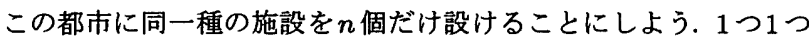
の施設は，その施設に割り当てられる住民が住む領域(誘致圈)をも つ筈である.この誘致圈を，便宜上“区”と呼ぶことにする.ここで 現実の施設とその誘致圈 (例えぼ小学校と小学校区，区役所と区など) を見ると，1つ1つの区の大きさや人口にあまり大きな差異がない場 合も多い，そこで，本研究のモデルでは全ての区の形状は互いに合 同と見做して巨視的に議論を進める.このとき，区の人口は一律に $P / n$ ，区の面積は一律に $S / n$ となる．さらに次を記述しておく：

$\nu=($ 住民 1 人が 1 年に施設を利用する回数の平均值) [回], $(1)$
$u=(1$ 施設に 1 年間に割り当てられる延べ客数 $)=\nu \times \frac{P}{n} .(2)$

\section{1 施設建設・運営費}

まず次を定義する：

$$
p(u)=(1 \text { つ施設の年当たり建設・運営費 })[\text { 円]. }
$$

つまり施設建設・運営費を, 割り当てられる客数uの函数とするのて ある. $p(u)$ は $u$ の増加函数と見做すのが自然であろう. 加えて, 経営 学的な観点からは, 費用にuの規模の効果が働くものと考えるべき である.このような訳で, $p(u)$ が欣を満たすものと想定する：

【単調增加性】 $p^{\prime}(u) \geq 0$, 【凹性】 $p^{\prime \prime}(u) \leq 0$.

これらを満たす典型的な函数として，次を考察の対象とする：

$$
p^{\text {需乘 }}(u)=a+b u^{c} \quad(a, b \geq 0 ; 0<c \leq 1) .
$$

aならびにbがともにゼロとなることはないものとする．係数設定の 相違による，函数の特徵を以下に記しておく(図 1 参照) : (i) $b=0$ の

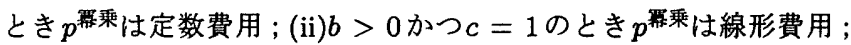

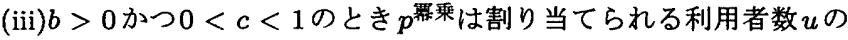
規模の効果を反映した費用.

(5) 式で $a$ は固定費文献3)を意味し，定額の運営費と用地費・建設 費の年当たり償還分 (の現在価値文献3) $)$ とを合算したものと見做され る. (5)の $(a, b, c)$ を適切に設定すれば，広範なコスト函数が設けら れる. 問題の構造を解明する上で,こうした典型的な函数形で一般 論を展開しておくことには意味があるものと思われる.

\section{2 住民の交通費}

1つの区の住民が施設を訪れるための交通費を設定したい.ここて は，住民から施設への平均距離から出発した積算を行うことにする。

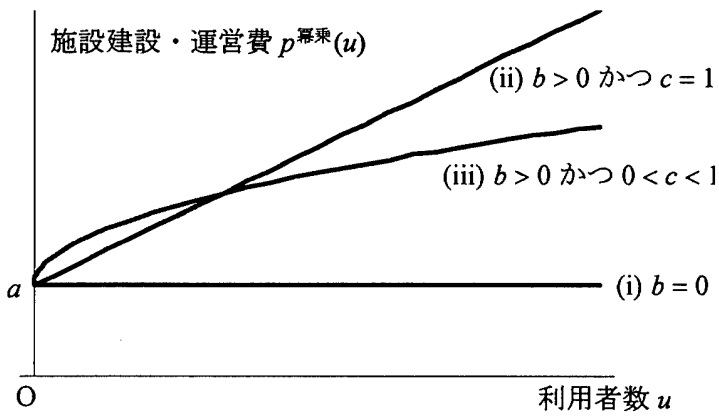

図1係数設定と施設運嫦費の概形。

区の面積は一律に $S / n$ だから，区のスケールは $\sqrt{S / n}$ である. よっ て, 住民から施設への平均距離を $\bar{r}(n)[\mathrm{km}]$ とおくと, 大局的には

$$
\bar{r}(n)=\kappa \sqrt{S / n}
$$

と表せる.ここでんは，(イ)距離の定義，(口)区の形状ならびに(ハ) 施設位置の三者に依存する定数である．ちなみに直線距離の下で，区 をそれぞれ円船，正六角形，正方形，正三角形と見做し，施設がそ

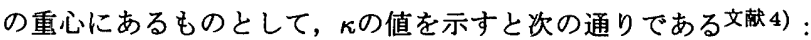

$$
\begin{aligned}
\kappa_{\text {円 }} & =\frac{2}{3 \sqrt{\pi}} \simeq 0.3761, \\
\kappa_{\text {正六角形 }} & =\frac{4+3 \ln 3}{6 \sqrt{6} \sqrt[4]{3}} \simeq 0.3772, \\
\kappa_{\text {正方形 }} & =\frac{\sqrt{2}+\ln (1+\sqrt{2})}{6} \simeq 0.3826, \\
\kappa_{\text {正三角形 }} & =\frac{2 \sqrt{3}+\ln (2+\sqrt{3})}{9 \sqrt[4]{3}} \simeq 0.4036 .
\end{aligned}
$$

住所と最寄りの施設の往復距離の平均值は， $2 \bar{r}(n)$ で与えられる。

続いて次を定義する：

$\alpha=$ (単位移動費) $[\mathrm{円} / \mathrm{km}]$

$=($ 単位交通費 $)[\mathrm{円} / \mathbf{k m}]+($ 単位距離の移動に要する時間を

貨幣価值に換算したもの) [円/km].

単位交通費とは単位距離を移動するための平均交通費であり，都市 交通網の発達度合いや住民の交通手段選択に依存すべきものである. この単位交通費に, 単位距離移動の時間費用を加えて単位移動費 $\alpha$ と した.このとき，区の住民が住所と施設の間を往復するために負担 する交通費の総額を $q$ とすると，次式の通りに定式化される：

$$
q=2 \bar{r}(n) \times \alpha \times \nu \times \frac{P}{n}=2 \nu \kappa \alpha P S^{1 / 2} n^{-3 / 2} .
$$

\section{3. 総費用の最小化問題}

\section{1 定式化}

都市全体での建設・運営費を $f(n)$ としよう。これは $p(u)$ を $n$ 倍し て得られる：

$$
f(n)=n p(u)=n p\left(\frac{\nu P}{n}\right) .
$$

都市全体での交通費を $g(n)$ とする．これは $q$ を $n$ 倍して得られる：

$$
g(n)=n q=2 \nu \kappa \alpha P S^{1 / 2} n^{-1 / 2} .
$$


両者を合算すれば都市住民の総費用負担 $(T(n)$ とする)が与えられる：

$$
\begin{aligned}
T(n) & =f(n)+g(n) \\
& =n p\left(\frac{\nu P}{n}\right)+2 \nu \kappa \alpha P S^{1 / 2} n^{-1 / 2}
\end{aligned}
$$

以下では最適化問題

$$
\text { minimize } T(n)
$$

の解を追求したい. $n$ は区数だから本来は自然数である. しかし，本 論文の目的は(i) 最適解の存在証明ならびに(ii) 最適区数の解析学的 特徴の明示である.そこで便宜上実数として扱うことにする.

まず 3.2 節で, 施設建設・運営費が票乗型の場合に最適解が一意的 に存在することを証明する。この証明は，区数に拘ることの本質的な 意味を示唆している. 次に 3.3 節では, 票乗型の式で特に $c=1$ とし た場合 (すなわち建設・運営費が線形函数の場合)の解を示す.この設 定下で得られる最適区数は簡潔で美しい性質を持つ. 同節では, 住民 1 人当たりの費用負担額が都市人口密度の減少函数となることも示さ れる. 加えて, 人口密度が異なる 2 つの都市の合併前後で, 住民の費 用負担が変化する様子にも焦点を当てる. 続く 3.4 節では, $c=1 / 2$ とした場合の解が 3 次方程式の実根に基づき記述されることを示す. さらに 3.5 節では, 覀乗型とは限らない一般の $p(u)$ の下でも, 区数を 最適に設ければ, 住民 1 人当たりの費用負担額が都市人口密度の減 少函数となることが証明される.これは人が集まって住むことの合 理性を本モデルの立場から明示するものとして興味深い.

3.2 施設の建設・運営費が票乗型の場合 一解の存在の一意性一 (5)を(15)に代入して得られる目的函数を $T$ 霖乘 $(n)$ とする :

$$
T^{\text {䚈乘 }}(n)=a n+b(\nu P)^{c} n^{1-c}+2 \nu \kappa \alpha P S^{1 / 2} n^{-1 / 2} .
$$

\section{ここで最適化問題}

$$
\text { (問題 1) minimize } T^{\text {路乘 }}(n)
$$

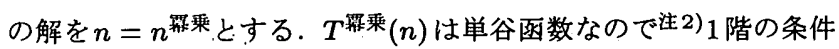

$$
T^{\text {䅇乘 }}(n)=a+b(1-c)(\nu P)^{c} n^{-c}-\kappa \nu \alpha P \sqrt{S} n^{-3 / 2}=0
$$

が最適化のための必要十分条件となる. ここで $x=n^{-c}$ と定義して 1 階の条件を書き換えると次式が得られる：

$$
x^{\frac{3}{2 c}}-A x-B=0
$$

ただし $A, B$ は次の通りに定義した(定義により $A, B$ は非負)：

$$
A=\frac{b(1-c)}{\kappa \alpha(\nu P)^{1-c} S^{1 / 2}}, \quad B=\frac{a}{\kappa \nu \alpha P S^{1 / 2}} .
$$

いま(18)式の $B$ を右辺に移項し, 両辺を $x$ で除すと次式が得られる：

$$
x^{\frac{3}{2 c}-1}-A=\frac{B}{x}
$$

係数の条件 $0<c \leq 1$ より

$$
\frac{3}{2 c}-1 \geq \frac{1}{2}
$$

である.よって $x^{\frac{3}{2 c}-1}-A$ は切片がー $A$ の単調増加函数. これが双 曲線 $B / x$ と $x>0$ の範囲で唯 $1 つ$ 交点を持つことは明らかである. よって, (18)の正の実根 $x^{*}$ を求めさえすれば, 求める最適区数が

$$
n^{\text {霙乘 }}=\frac{1}{\left(x^{*}\right)^{1 / c}}
$$

と与えられることが分かる

以上によって，次が証明された注3)：

【定理 1】建設・運営費が(5)式の囬乗型の場合, 総コ スト $T^{\text {羅乗 }}(n)$ の最小解 $n=n$ 筷乗が一意的に存在する.

ただし，任意の票乗型施設建設・運営費に対して最小解が陽に求め られるわけではない.それが可能なのは，後述するようにc=1の場 合と $c=1 / 2$ の場合である. それ以外の場合に最小解 $n$ 晸乗を求める には，例えば1階の条件にNewton-Raphson 法を適用すればよい，

3.3 耑乗型の建設・運営費で $c=1$ とした場合 $($ 線形の建設・運営費 $)$ (5)式で $c=1$ とした場合を

$$
p^{\text {線形 }}(u)=a+b u
$$

と記す．(23)を $(15)$ に代入した総費用を $T^{\text {線形 }}(n)$ としよう：

$$
T^{\text {線形 }}(n)=a n+b \nu P+2 \nu \kappa \alpha P S^{1 / 2} n^{-1 / 2} \text {. }
$$

このときの最適化問題

(問題2) minimize $T^{\text {線形 }}(n)$

の解を $n=n$ 線形とする. 目的函数の 2 階の微保数は

$$
T^{\text {線形" }}(n)=\frac{3 \nu \kappa \alpha P S^{1 / 2}}{2} n^{-5 / 2}>0
$$

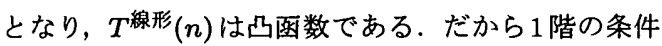

$$
T^{\text {線形 }}(n)=a-\nu \kappa \alpha P S^{1 / 2} n^{-3 / 2}=0
$$

を満たす $n$ が大域的な最適解である(もっとも，最適性は 3.2 節で既 に証明済であるが).これを具体的に求めると次の通りである：

$$
n^{\text {線形 }}=\left(\frac{\nu \kappa \alpha}{a}\right)^{2 / 3} P^{2 / 3} S^{1 / 3} .
$$

つまり次が成立することが示された：

【定理 2】施設運営費が利用者数の線形函数のとき，最 適施設数は人口の $2 / 3$ 乗と都市面樻の $1 / 3$ 乗とに比例 する : $\quad n^{\text {線形 }} \propto P^{2 / 3} S^{1 / 3}$.

ここで $(27)$ の解を(24)に代入・整理すると最適施設数の下での総 費用負担額を得る：

$$
T^{\text {線形 }}\left(n^{\text {線形 }}\right)=\nu b P+3 \delta P^{2 / 3} S^{1 / 3} \text {. }
$$


ただし反は次の通りに定義した：

$$
\delta=a^{1 / 3}(\nu \kappa \alpha)^{2 / 3}
$$

このときの一人当たり費用負担額を線形として求めると次の通り：

$$
\phi^{\text {線形 }}=\frac{T^{\text {線形 }}\left(n^{\text {線形 }}\right)}{P}=\nu b+3 \delta\left(\frac{S}{P}\right)^{1 / 3}=\nu b+3 \delta \rho^{-1 / 3} \text {. }
$$

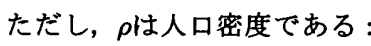

$$
\rho=P / S\left[\text { 人 } / \mathrm{km}^{2}\right] .
$$

つまり，次の成立が示された：

【定理3】施設運営費が利用者数の線形函数のとき，最 適施設数の下での住民 1 人当たり費用負担額は，人口密 度の-1/3 乗の線形函数である.

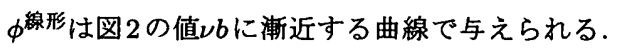

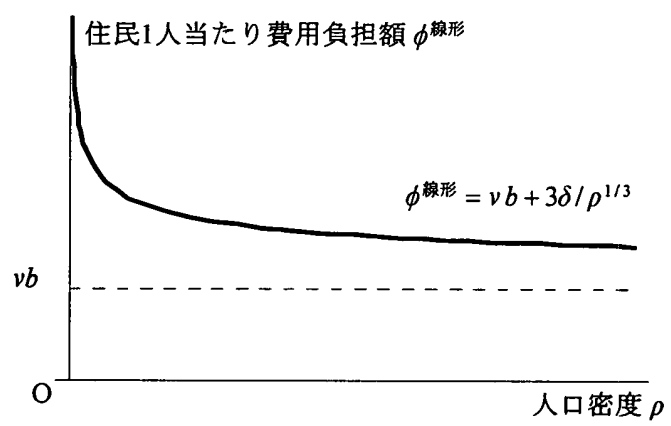

图 2 住民 1 人当たり費用負担額が人口密度 $\rho$ の減少函数である様子

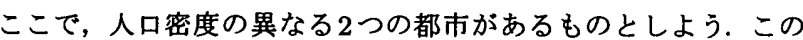
2 都市が合併した場合，住民 1 人当たり平均費用負担額はどのような 影響を受けるだろうか.この影響を明示して，都市施設計画論の立 場から合併を位㯰つける試みとしたい。

都市 $j$ の人口と面積を $\left(P_{j}, S_{j}\right)$, 人口密度を $\rho_{j}=P_{j} / S_{j}$ とし, 施設

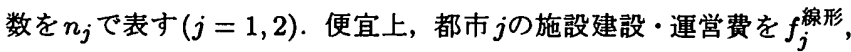
移動費を $g_{j}$ で表そう:

$$
\begin{aligned}
f_{j}^{\text {湶形 }}\left(n_{j}\right) & =n_{j} p^{\text {線形 }}\left(\frac{\nu P_{j}}{n_{j}}\right)=a n_{j}+b \nu P_{j}, \\
g_{j}\left(n_{j}\right) & =2 \nu \kappa \alpha P_{j} S_{j}^{1 / 2} n_{j}^{-1 / 2} .
\end{aligned}
$$

まずは合併前の各都市での，住民1人当たり平均費用負担額を確 認しておこう. 都市 $j$ 総コストを $T_{j}^{\text {線形 }}\left(n_{j}\right)$ とすると

$$
\begin{aligned}
T_{j}^{\text {湶形 }}\left(n_{j}\right) & =f_{j}^{\text {線形 }}\left(n_{j}\right)+g_{j}\left(n_{j}\right) \\
& =a n_{j}+b \nu P_{j}+2 \nu \kappa \alpha P_{j} S_{j}^{1 / 2} n_{j}^{-1 / 2}
\end{aligned}
$$

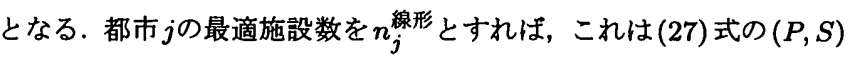
を $\left(P_{j}, S_{j}\right)$ で圈き換えれば得られる：

$$
n_{j}^{\text {線形 }}=\left(\frac{\nu \kappa \alpha}{a}\right)^{2 / 3} P_{j}^{2 / 3} S_{j}^{1 / 3} \text {. }
$$

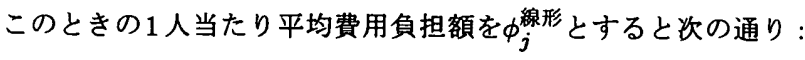

$$
\phi_{j}^{\text {線形 }}=\nu b+3 \delta \rho_{j}^{-1 / 3} \text {. }
$$

次に合併後の住民 1 人当たり平均費用負担額を求める. 合併後の (新)都市は, 人口密度の異なる $2 つ の$ 地域からなる.ただし合併後の 都市に対する総コストは

$$
T_{\text {合伻後 }}\left(n_{1}, n_{2}\right)=T_{1}^{\text {線形 }}\left(n_{1}\right)+T_{2}^{\text {線形 }}\left(n_{2}\right)
$$

であるから， $T_{\text {合阱後 }}\left(n_{1}, n_{2}\right)$ の最小解の方も単に $\left(n_{1}^{\text {線形 }}, n_{2}^{\text {線形 }}\right)$ と求め られることに注意をせられたい. 合併の後, 新都市の施設建設・運 営費 $f_{1}^{\text {線 }}\left(n_{1}^{\text {線形 }}\right)+f_{2}^{\text {線形 }}\left(n_{2}^{\text {線形 }}\right)$ は全住民 $\left(人\right.$ 数は $\left.P_{1}+P_{2}\right)$ による税負 担で賄われる. したがって, 新都市全体での, 施設建設・運営費の住 民 1 人当たり平均負担額を $v$ とすると

$$
\begin{aligned}
v & =\frac{f_{1}^{\text {線形 }}\left(n_{1}^{\text {線形 }}\right)+f_{2}^{\text {線形 }}\left(n_{2}^{\text {缐形 }}\right)}{P_{1}+P_{2}} \\
& =\delta\left(\frac{P_{1}}{P_{1}+P_{2}} \rho_{1}^{-1 / 3}+\frac{P_{2}}{P_{1}+P_{2}} \rho_{2}^{-1 / 3}\right)+\nu b
\end{aligned}
$$

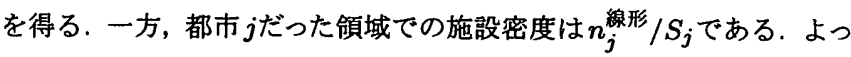
て，都市 1 だった領域と都市 2 だった領域とでは，一般に，移動費の 住民1人当たり平均負担額は異なる.そこで $w_{j}$ を都市 $j$ だった領域で の交通费の住民1人当たり平均負担額として記すと次を得る：

$$
w_{j}=\frac{g_{j}\left(n_{j}^{\text {線形 }}\right)}{P_{j}}=2 \delta \rho_{j}^{-1 / 3}
$$

これらに基ついて，合併後の，元は都市 1 だった領域の 1 人当たり平 均費用負担額を $\phi_{\text {合併後の } 1}$ として計算する：

$$
\begin{aligned}
& \phi_{\text {合併後の } 1}^{\text {形 }}=v+w_{1} \\
& \quad=\delta\left(2 \rho_{1}^{-1 / 3}+\frac{P_{1}}{P_{1}+P_{2}} \rho_{1}^{-1 / 3}+\frac{P_{2}}{P_{1}+P_{2}} \rho_{2}^{-1 / 3}\right)+\nu b .
\end{aligned}
$$

さて，合併の功罪を観るために，都市 1 の領域の住民 1 人当たり 平均费用負担額の合併前後での差異を $\epsilon_{1}$ として記述する :

$$
\begin{aligned}
\epsilon_{1} & =\phi_{\text {合併後の } 1}-\phi_{1}^{\text {線形 }} \\
& =\frac{\delta P_{2}}{P_{1}+P_{2}}\left(\rho_{1} \rho_{2}\right)^{1 / 3}\left(\rho_{1}^{1 / 3}-\rho_{2}^{1 / 3}\right) .
\end{aligned}
$$

これにより, $\rho_{1}<\rho_{2} \Rightarrow \epsilon_{1}<0$ が分かる. すなわち, 次の定理 の成立が判明した：

【定理 4】施設建設・運営費を利用者数の線形函数とし， 人口密度の異なる 2 つの都市を想定する. 都市全体での 施設建琂・運営費と移動費の和を最小化すへくく施設数を 決定するものと約束しょう.この状況下では，人口密度 の低い都市の住民 1 人当たり平均費用負担額は，合併に よって減少する(人口密度が高い方のそれは増加する).

即ち人口密度の低い都市は, 高い都市と合体し全体の総コストを最 小化すべく施設を建設・運営してもらうのが賢明である．逆に，1つ 


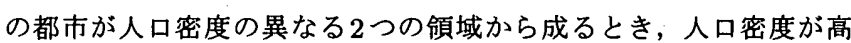
い方の住民は，低い領域を切り離せば，平均費用負担を減額できる．

3.4 罵乗型の建設・運営費で $c=1 / 2$ の場合 (規模の効果の 1 典型) (5) 式で $c=1 / 2$ とした場合を

$$
p^{\text {规模 }}(u)=a+b u^{1 / 2}
$$

とする.このときの目的函数は(15)より

$$
T^{\text {规模 }}(n)=a n+b(\nu P n)^{1 / 2}+2 \nu \kappa \alpha P S^{1 / 2} n^{-1 / 2}
$$

となる．そこで最適化問題

$$
\text { (問題 3) minimize } T^{\text {規模 }}(n)
$$

の解を $n=n$ 规模とする. 1 階の条件は $(18)$ で $c=1 / 2$ と直いた

$$
x^{3}-A x-B=0
$$

だから,これの正の実根を求めればよい。ただし

$$
A=\frac{b}{2 \kappa \alpha(\nu P S)^{1 / 2}} ; \quad B=\frac{a}{\nu \kappa \alpha P S^{1 / 2}} .
$$

である.(44)をCardanoの方法例えば文献5)によって解いた：

$$
\begin{array}{r}
x_{t}=\omega^{t} \sqrt[3]{\frac{B}{2}+\sqrt{\frac{B^{2}}{4}-\frac{A^{3}}{27}}}+\omega^{-t} \sqrt[3]{\frac{B}{2}-\sqrt{\frac{B^{2}}{4}-\frac{A^{3}}{27}}} \\
(t=0,1 ; 2) .
\end{array}
$$

$\omega$ は 1 の立方根である $: \omega=(-1+\sqrt{3} i) / 2 . こ こ て ゙ ~ t=0$ の場合の解

$$
x_{0}=\sqrt[3]{\frac{B}{2}+\sqrt{\frac{B^{2}}{4}-\frac{A^{3}}{27}}}+\sqrt[3]{\frac{B}{2}-\sqrt{\frac{B^{2}}{4}-\frac{A^{3}}{27}}}
$$

は正の実数である注4)。よって最適施設数は次の通りである：

$$
n^{\text {规模 }}=1 / x_{0}^{2} \text {. }
$$

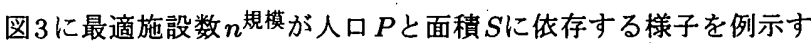
る. ただし，一連の係数を次のように置いた : $a=2 \times 10^{8}$ 円, $b=10^{5}$ 円， $\kappa=0.4, \alpha=500$ 円 $/ \mathrm{km}, \nu=10$ 回.

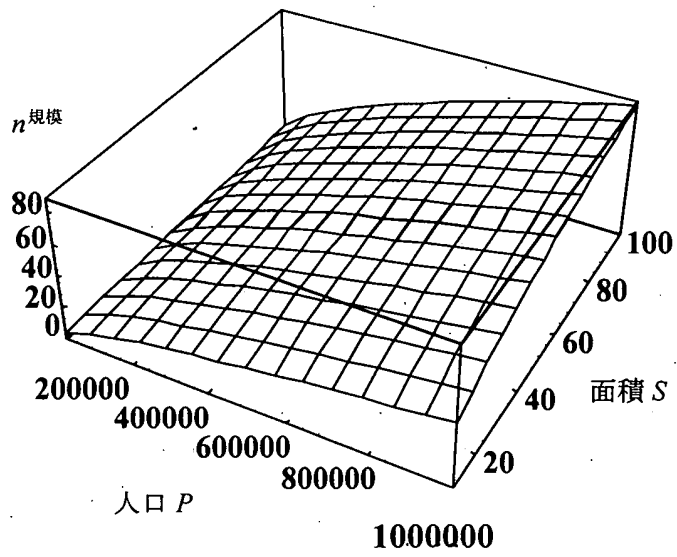

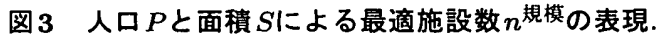

\subsection{1 人当たり費用負担額に関する一般論}

3 節を楴めくくるに当たって，次を述べたい：

【定理 5】総コストを最小化すべく区数を決める，とい う条件の下では，住民 1 人当たりの費用負担額が都市人 口密度の減少函数となる.

このことが線形の施設建設・運営費の下で成立するのは【定理 3】で 述べた．実はこれが線形費用のみならず，一般の施設建設・運営費 $p(u)$ のでも成り立つのである.

一般の施設建設・運営費の下での総費用は

$$
T(n)=n p\left(\frac{\nu P}{n}\right)+2 \nu \kappa \alpha P S^{1 / 2} n^{-1 / 2}
$$

であった. よって 1 人当たりの費用負担額 $\phi(n)$ は次式の通り :

$$
\phi(n)=\frac{T(n)}{P}=\frac{n}{P} p\left(\frac{\nu P}{n}\right)+2 \nu \kappa \alpha S^{1 / 2} n^{-1 / 2} .
$$

$T(n)$ 最小化のための 1 階の条件

$$
T^{\prime}(n)=p\left(\frac{\nu P}{n}\right)-\frac{\nu P}{n} p^{\prime}\left(\frac{\nu P}{n}\right)-\nu \kappa \alpha P S^{1 / 2} n^{-3 / 2}=0
$$

を満たす解を $n^{*}$ と固く $\left(\right.$ 即ち $\left.T^{\prime}\left(n^{*}\right)=0\right)$ ）このとき次を示せばよい：

$$
\frac{\partial \phi\left(n^{*}\right)}{\partial \rho}<0
$$

人口密度の定義 (31) から

$$
\frac{\mathrm{d} P}{\mathrm{~d} \rho}=S
$$

であることに着目して微分の連鎖則を適用すれば,

$$
\frac{\partial \phi\left(n^{*}\right)}{\partial \rho}=\frac{\partial \phi\left(n^{*}\right)}{\partial P} \times \frac{\mathrm{d} P}{\mathrm{~d} \rho}=\frac{\partial \phi\left(n^{*}\right)}{\partial P} \times S
$$

であることが分かる: ここで $\partial \phi\left(n^{*}\right) / \partial P$ を計算すると

$$
\begin{aligned}
\frac{\partial \phi\left(n^{*}\right)}{\partial P}= & \left(\frac{1}{P} \frac{\partial n^{*}}{\partial P} \cdot-\frac{n^{*}}{P^{2}}\right) p\left(\frac{\nu P}{n}\right) \\
& +\frac{n}{P}\left(\frac{\nu}{n^{*}}-\nu P \frac{\partial n^{*}}{\partial P} n^{-2}\right) p^{\prime}\left(\frac{\nu P}{n^{*}}\right) \\
& \quad-\nu \kappa \alpha S^{1 / 2} \frac{\partial n^{*}}{\partial P} n^{*-3 / 2} \\
= & \frac{1}{P} \cdot \frac{\partial n^{*}}{\partial P} \cdot T^{\prime}\left(n^{*}\right)-\frac{n^{*}}{P^{2}}\left\{T^{\prime}\left(n^{*}\right)+\nu \kappa \alpha P S^{1 / 2} n^{-3 / 2}\right\} \\
= & -\frac{\nu \kappa \alpha S^{1 / 2}}{P n^{1 / 2}}\left(T^{\prime}\left(n^{*}\right)=0\right. \text { より)}
\end{aligned}
$$

を得る.(54)を(53)に代入して次の結果を得る：

$$
\frac{\partial \phi\left(n^{*}\right)}{\partial \rho}=-\frac{\nu \kappa \alpha S^{3 / 2}}{P n^{1 / 2}}<0 .
$$

以上が【定理 5】の証明である. 区数を最適に設定するという理想的 な条件下にせよ, 住民の集住の利益(すなわち人口規模の効果)が明 示されたことに意義がある.

\section{4. 政令指定都市の区数の分析}

さて今回は特に,【定理 2】の立場から, 都市データの吟味を試 みる. 具体的には政令指定都市の区の数を祖上に上せよう. 
表 1 政令指定都市のデータ (1995 年).

\begin{tabular}{|c|c|c|c|c|c|c|c|}
\hline 都市名 & $\begin{array}{r}\text { 人口 } P \\
\text { [人] }\end{array}$ & $\begin{array}{l}\text { 面積 } S \\
{\left[\mathrm{~km}^{2}\right]}\end{array}$ & $\begin{array}{r}\text { 区数 } n \\
\text { [個] }\end{array}$ & $\begin{array}{r}P / n \\
\text { [人] }\end{array}$ & $\begin{array}{l}S / n \\
{\left[\mathrm{~km}^{2}\right]}\end{array}$ & $\begin{aligned} & \xi \\
&= P^{2 / 3} S^{1 / 3} \\
& {\left[(人 \cdot \mathrm{km})^{2 / 3}\right] }\end{aligned}$ & $\begin{array}{c}\zeta=n / \xi \\
\left(\times 10^{-5}\right) \\
{\left[\text { 個 }(\text { 人.km })^{-2 / 3}\right]}\end{array}$ \\
\hline 札幌 & 1757025 & 1121.18 & 9 & 195225 & 124.58 & 151267 & 5.95 \\
\hline 仙台 & 971297 & 783.50 & 5 & 194259 & 156.70 & 90417 & 5.53 \\
\hline 千葉 & 856878 & 272.08 & 6 & 142813 & 45.35 & 58458 & 10.26 \\
\hline 東京 23 区 & 7967614 & 617.65 & 23 & 346418 & 26.85 & 339729 & 6.77 \\
\hline 横浜 & 3307136 & 435.25 & 18 & 183730 & 27.20 & 168221 & 10.70 \\
\hline 川崎 & 1202820 & 142.09 & 7 & 171831 & 20.30 & 59019 & 11.86 \\
\hline 名古屋 & 2152184 & 326.37 & 16 & 134512 & 20.40 & 114769 & 13.94 \\
\hline 京都 & 1463822 & 610.21 & 11 & 133075 & 55.47 & 109350 & 10.06 \\
\hline 大阪 & 2602421 & 220.37 & 24 & 108434 & 9.18 & 114280 & 21.00 \\
\hline 神戸 & 1423792 & 543.92 & 9 & 158199 & 60.44 & 103310 & 8.71 \\
\hline 広島 & 1108888 & 740.18 & 8 & 138611 & 92.52 & 96911 & 8.26 \\
\hline 北九州 & 1019598 & 482.23 & 7 & 145657 & 68.89 & 79440 & 8.81 \\
\hline 福岡 & 1284795 & 336.40 & 7 & 183542 & 48.06 & 82194 & 8.52 \\
\hline
\end{tabular}

表 1 の 1 列から 4 列に, 1995 年 (平成 7 年)における政令指定都市の 都市名・人口 $P$ ・面積 $S$ ・ 区数 $n$ のデータを示す. そして本論文冒頭 で言及した平均值の例として, 区当たり人口 $P / n$ ならびに区の平均 面積 $S / n$ も $5 \cdot 6$ 列に示しておく.

$5 \cdot 6$ 列の平均值から何が分かるだろうか. 区平均人口は 108,434 人(大阪市)から 346,418 人(東京都)の間に散らばっている．まずは， よく行われるように，この指標によって区数の多塞を論じてみよう. 先ず，大阪市の区平均人口の少なさ $(108,434$ 人)に気付く. また, 例 えほ，東京 23 区と仙台市の区平均人口を比較すると前者は後者の 2 倍弱であることにも気が付く $(346,418$ 人と 194,259 人).ある人はこ れらを基に「大阪市の区数は過大」，「東京の区数は過小」あるいは 「仙台市の区数は削減すへし」等の意見を述へるかもしれない，しか し，こうした意見に直ちに耳を傾けるのは危険である．何故ならば (本論文の冒頭で述べた通り)この区平均人口には都市の “空間的な広 がり”という要件が反映されていないからである．そこで大阪市，東 京 23 区ならびに仙台市における区の平均面積に目を移すと $9.18 \mathrm{~km}^{2}$, $26.85 \mathrm{~km}^{2}$ ならびに $156.70 \mathrm{~km}^{2}$ である. この面積の情報を区の平均人 ロという情報に付すことで，何が明らかになるだろうか. 実はこれ を無手勝流に論ずるのは困難だから，本研究の数理モデルを提案し ているのである. 3節の成果を踏まえて議論を行ってみよう.

\section{本研究の【定理 2】は}

\section{最適施設数は人口の $2 / 3$ 乗と面積の $1 / 3$ 乗に比例する}

というものであった．そこで各政令指定都市に関して

$$
\xi=P^{2 / 3} S^{1 / 3} \quad\left[(\text { 人 } \cdot \mathrm{km})^{2 / 3}\right]
$$

を表 1 の 7 列目に示した. $\xi$ と実際の区数 $n$ を比較するために, 比を

$$
\zeta=n / \xi \quad\left[\text { 個 } \cdot(\text { 人 } \cdot \mathrm{km})^{-2 / 3}\right]
$$

として算出した (表 1 の最終列). 大阪市だけは飛びぬけて大きな值を取 っている $\left(21.00 \times 10^{-5}\right)$ が, 他は $5.53 \times 10^{-5}$ (仙台市) から $13.94 \times 10^{-5}$ の範囲に収まっており， $n$ と $\xi$ との関係は比較的に安定している.す なわち，政令指定都市の区数は存外適切に設定されているのではな
いか，という推測が成り立つ．〈值でグルーピングを行った例を表 2 に示す. らが大きいほどその都市の施設数が充実していると言える.

表 2 指標による都市の分類.

\begin{tabular}{|r||l|}
\hline \multicolumn{1}{|c|}{$\left(\times 10^{-5}\right)$} & 都市名 \\
\hline \hline 5.0 以上 7.0 末満 & 仙台・柇幌・東京 23 区 \\
7.0 以上 9.0 未満 & 広島・福岡・神戸 北九州 \\
9.0 以上 11.0 未満 & 京都・千葉・横浜 \\
11.0 以上 13.0 未満 & 川崎 \\
13.0 以上 15.0 未満 & 名古屋 \\
15.0 以上 & 大阪 \\
\hline
\end{tabular}

$\xi$ 值と区数 $n$ の関係を図4にプロットしておく，これを見ると，大 阪市の現実の区数は過大で，東京 23 区の区数は過少であるのが読み 取られる. また, $\xi$ 値と区数 $n$ の間に線形関係の存在が読み取られる. ちなみに，大阪を除去した上で原点を通る直線回帰を行うと

$$
n=8.04 \times 10^{-5} \xi \quad\left(R^{2}=0.67\right)
$$

を得る(図4の直線). この線形関係からの乘離をもって施設の多塞を 議論する礎となせるのではないだろうか. これが筆者の主張である.

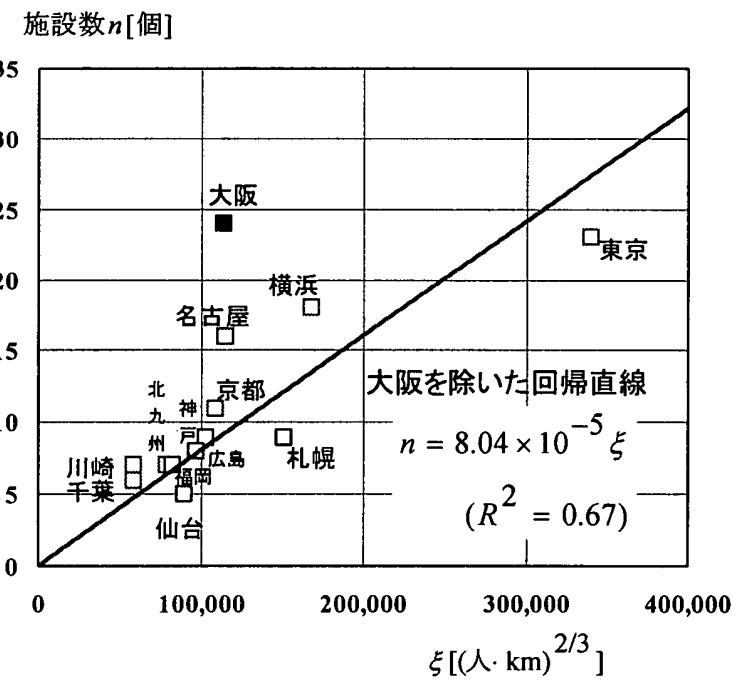

図4 $\xi$ 値と区数 $n$ との関係. 
いま前述の東京 23 区と仙台市とを比較すると，らの值は $6.77 \times 10^{-5}$ と $5.53 \times 10^{-5}$ となっている. 柿大きいほど区の数が多いと考えられ のだから；前述の1つの意見「東京には区の数が少なすぎる」は(仙 台市と比較する限りにおいては)的外れなものである可能性が高い.

一方，大阪市に目を向けると，䐈は $21.00 \times 10^{-5}$ と他に抜き んでて大きい，単なる平均值でなく，移動コストをも考慮した我々の 立場からしても，大阪市の区の数はかなり大きいのである。それは 何故であろうか. また，他の都市を見ても，らの值には，それなりの バラツキがあるが，その原因は何だろうか。この問いに答えること はそれほど簡単ではない. しかし幾つかの仮説は述べられる：(a) 区 役所がサービスを提供する相手は住民だけではない! それも組み込 んだモデル化を適切に行えば，らのバラツキが抑えられるかもしれな い; (b) 都市によって区役所の運営コスト函数が異なるため, たとえ 適切に決定したとしても区数は異なったものとなる；(c)都市によっ て住民の移動コストが異なるため, たとえ適切に決定したとしても 区数は異なったものとなる :: (d) 過去の時点で区数を適切に決定して も, 人口の変化に伴って, 現時点では適切な区数でなくなっている.

上記の (a)について付言する. 現実の区役所は，住民サービスの みならず, 事業所へのサービスも行っている.したがって，区役所の 数は事業所の数の多賽にも影響されるべきものである.これを踏ま

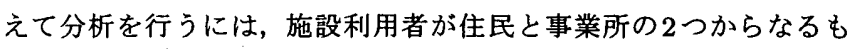
のとしてモデル化すればよい.これは今後の課題である. (b) の運 営コストに関しては，現実のコストを推定した上で利用者数との関 係を詳しく分析する必要がある．これも今後の課題である. (c)は, 住民の主たる交通機関の種類が重要であることを示唆している. 本 研究では住民の単位移動費を(11)式の $\alpha$ で与えた。この数值が大き いほど(12) 式の移動費用 $q$ が総費用 $T$ に占める比重が大きい. そして

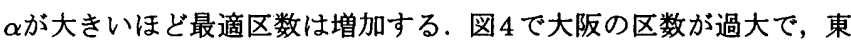
京の区数が過小であると述べた：これは，大阪における単位移動費 $\alpha$ が他都市に比べて大きく, 東京23 区の単位移動費が他都市に比べて 小さいことを反映しているのかもしれない，ただし，厳密な議論を 行うには, 各都市の交通機関分担率の詳細な分析が必要である.ま た, 単位距離の移動に関わる時間価值を都市毎に調査する必要もあ る(もしかしたら大阪では他都市よりも“時は金なり”という意識が 高いのかもしれない). 最後の(d)は, 最適な区数が時系列的に変化 することを示唆する．新たに複数の施設を設けるとき, 建設時点で の最適な施設数を前提にして計画を行うか, あるいは, 将来時点に おける都市人口を見越して計画を行うか?これが都市施設の建筑計 画における重要なテーマであることは論を俟たない.

\section{5. まとめ}

施設の建設・運営費と住民の移動費に関する単純な想定の下で， 最適な施設数を議論した。まず, 施設建設・運営費が利用者数の凹 な票乗型函数で与えられる, という典型的な場合に, 総コストの最 小解が一意に存在することが【定理 1】で示された．続いて施設の建 設・運営費が利用者数の線形函数の場合に，最適な施設数に関する 見通しの良い結果【定理2】が与えられた。これによって，人口增加 に対応した施設整備水準を設定することが出来る. 例えば他の条件 が不変で，人口だけが 2 倍になれば，施設数は $2^{2 / 3} \simeq 1.59$ 倍にすべ
きなのである. また, これらによって, 面積も人口も異なる複数の都 市の施設充実度を論理的に比較することが可能となる (4節).

【定理 3】と【定理5】も示唆的である.これは施設数を適切に与 えた場合, 人口密度が高いほど 1 人当たりの費用負担が小さいこと を物語っているのである.これは, 住民にとっての“集住の利益”を 意味している. 古来, 人は何故に集まって住むのか, という疑問への 解答は種々の論理的枠組みによって追求されてきた。ここでの内容 は, 施設に関わるコストを空間的な枠組みに基づいて考察すること によって，新たなる1つの解答を加えたものと言えよう.

施設を成り立たせるための最少人数という条件を捨象している点 では,【定理 4】の結果は理念的である．したがって，人口密度の低 い都市は高い都市に吸収されるべしとか, 人口密度の低い領域は切 り離すべし，といった議論が単純にできる訳でもないだろう。しか し, 都市人口の粗密を施設計画論の枠組みによって理論的に取り上 げ明確な結論を゙得た，という点で意義がある. なお，この結果は3つ 以上の異なる人口密度に対しても自然に拡張できる.

一方, 3.4 節では施設建設・運営費が利用者数の平方根の線形函数 の場合に，最適施設数が陽に求められた。ただし“都市人口と都市 面積が最適施設数にどう効くか”という点で，3.2節の【定理 2】ほ どの見通しの良さはない: とはいえ，費用函数の係数を特定すれば, 結果は直ちに利用出来る. したがって, 3.4節の結果も都市設計の根 本に関わる重要な情報を与える可能性を秘めている.

以上, 本研究では

\section{“人口，面積ならびにその比であるところの人口密度と いう3つの基本的な量が都市施設計画において果たす} 役割”

が, これまでにない形で示された. なお, 前述の結果は, 実は私企 業が適正な店舖数を決定するための指針をも与え得る注1).

最後に, 本研究を都市計画の現場で直接的に役立てるのは困難な ことかもしれないが, 施設計画の背後にある論理的な宿命に関して, 新たなる認識を提供した点で意義があるものと考えている.

\section{謝辞}

コスト函数の設定等に関する有益なコメントを下さうた柳井 浩 教授(慶應義塾大学理工学部), 鈴木久敏教授(筑波大学経営システム 科学専攻), 福川忠昭教授(慶應義塾大学理工学部)に感謝致します. また日本語と数式の表現に関して貴重なご助言を下さった匿名の査 読者に謝意を表します。

\section{参考文献}

1) 柳澤 忠・谷村秀彦: 地域施設計画(新建築学大系 21) (彰国社; 1984).

2) 岡田光正・高橋鷹志 : 建築規模論 (新建築学大系 13) (彰国社, 1988). 3) 千住鎮雄・伏見多美雄 : 新版・経済性工学の基礎 (日本能率協会又 ネジメントセンター, 1994).

4) 栗田 治 : 不定形に関する距離分布の基礎, 慶應義塾大学理工学 部管理工学科 Technical Report, No.95008 (1995).

5) 一松 信-竹之内修編 : 改訂増補・新数学事典 (大阪書籍,1991). 6) 志賀浩二 : 複素数 30 講 (朝倉書店,1989). 
注

\section{注 1) [営利目的の店舗数決定モデルに関する定式化]}

例えばピザの宅配チェーンのような営業形態を想定し, 1 人の経営 者が $n$ 個の店舗を設けることにしよう．このときは, まず 2 節の(一 様に分布する)住民を客と見做す.そして

$$
p=(\text { 店舗の建設・運営費 })[\mathrm{円}]
$$

と定義し直そう.さらに客からの注文に応じて逐次的に商品の出前 を行うと想定する.そして，2節 (1)，(11)式の $\nu ， \alpha$ も

$\nu=($ 住民 1 人が 1 年に注文する回数の平均值)[回],

$\alpha=$ (配達のための単位移動費) $[$ 円 $/ \mathrm{km}]$

$=$ (配達のための単位交通费 $)+($ 単位距離の配達移動に要する

時間を人件費に換算した值 $[$ [円 $/ \mathbf{k m}]$

と膡き直そう.すると (12)式の $q$ は

$q=($ 経営者が負担する配達のための交通費の総額)[円]

と解釈されることになる．このときのTは経営者が負担する建設・運 営費と宅配交通費の和に他ならない，その最小化に関する解析学的 な知見は 3 節に述べる通りである.

注 2) $\left[T^{\text {票乘 }}(n)\right.$ が単谷函数であること]

問題の函数

$$
T^{\text {票乘 }}(n)=n+b(\nu P)^{c} n^{1-c}+2 \nu \kappa \alpha P S^{1 / 2} n^{-1 / 2}
$$

の各係数は全て正であるから，次が成立する:

$$
\lim _{n \rightarrow+0} T^{\text {䨳乘 }}(n)=\infty ; \quad \lim _{n \rightarrow+\infty} T^{\text {罢乘 }}(n)=\infty .
$$

したがって，区間 $(0, \infty)$ に極小值が(少なくとも) $1 つ$ 存在する. そし $\tau$, その極小值では 1 階の条件 $T^{\text {震乘 }}(n)=0$ が成立せねばならない. しかるに, 本文 $(20)$ 式を用いて説明したように,この1階の条件を

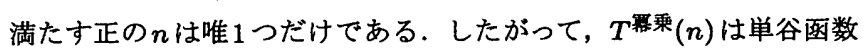
である.このとき 1 階の条件が大域的最小值であるための必要十分 条件である.

\section{注3）[解の一意性に関する別の定理］}

解の一意性を(必ずしも票乗型ではない)一般の建設・運営費 $p(u)$ に関して示すこともできる：

【定理 1A】 $p(u)$ が単調増加の凹函数で， $-p^{\prime \prime}(u)-$ $u p^{\prime \prime \prime}(u)<0$ を满足するものとする. このとき $T(n)$ の 最小解 $n^{*}$ が正の範囲に唯 1 つ存在する.

紙面が長くなり過ぎるので証明は割愛する. なお本文 (5)の票乗型函 数は, この- $p^{\prime \prime}(u)-u p^{\prime \prime \prime}(u)<0$ という性質を満足する. したがっ て，本文の【定理1】は実は【定理1A】の系と見做される.

注4) [ $x_{0}$ が正数であること]

示したいのは次のことである：
【定理】 $A>0, B>0$ のとき

$$
x_{0}=\sqrt[3]{\frac{B}{2}+\sqrt{\frac{B^{2}}{4}-\frac{A^{3}}{27}}}+\sqrt[3]{\frac{B}{2}-\sqrt{\frac{B^{2}}{4}-\frac{A^{3}}{27}}}
$$

は正数である.

\section{証明}

以下に $A$ と $B$ との相対的大小関倸によって $2 つ に$ 場合分けして証 明する。

[1] $(B / 2)^{2}-A^{3} / 27 \geq 0$ のとき

この場合は $A>0$ の条件により

$$
\frac{B}{2}>\sqrt{\left(\frac{B}{2}\right)^{2}-\frac{A^{3}}{27}}
$$

である. したがって， $x_{0}$ の 2 項ともに，3乗根号の内部は正である. よって $x_{0}$ は正数である.

[2] $(B / 2)^{2}-A^{3} / 27<0$ のとき

この場合は, $x_{0}$ の 2 つの 3 乗根号内部

$$
\frac{B}{2}+\sqrt{\frac{B^{2}}{4}-\frac{A^{3}}{27}} \text { と } \frac{B}{2}-\sqrt{\frac{B^{2}}{4}-\frac{A^{3}}{27}}
$$

は互いに共役な複素数である.いま便宜上

$$
\begin{aligned}
\lambda & =\frac{B}{2}, \\
\mu & =\sqrt{-\left(\frac{B}{2}\right)^{2}+\frac{A^{3}}{27}}
\end{aligned}
$$

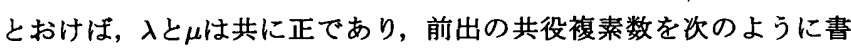
き換えることができる：

$$
\begin{aligned}
& z=\frac{B}{2}+\sqrt{\frac{B^{2}}{4}-\frac{A^{3}}{27}}=\lambda+\sqrt{-\mu^{2}}=\lambda+i \mu, \\
& \bar{z}=\frac{B}{2}-\sqrt{\frac{B^{2}}{4}-\frac{A^{3}}{27}}=\lambda-\sqrt{-\mu^{2}}=\lambda-i \mu .
\end{aligned}
$$

この両者の 3 乗根の和

$$
\sqrt[3]{z}+\sqrt[3]{\bar{z}}
$$

が正数であることを示せばよい.ところで，これが実数であることは

$h(u)$ が実係数の多項式で, $z$ と六が互いに共役な複素数

であるとき, $h(z)+h(\bar{z})=2 \Re(h(z))$ である

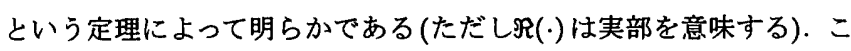
の定理はLeibnizによって予想され，後に証明された文献6).

本稿の題意に沿えば, $h(u)=u^{1 / 3}$ だから, $h(z)+h(\bar{z})=2 \Re\left(z^{1 / 3}\right)$ である.ここで $\lambda, \mu>0$ により，zの偏角 $\theta$ は $0<\theta<\pi / 2$ を満たす.よ って, $z^{1 / 3}$ の偏角 $\theta^{\prime}$ は $0<\theta^{\prime}<\pi / 6$ を満たす. したがって凡 $\left(z^{1 / 3}\right)>0$ が成り立つ. よって $\sqrt[3]{z}+\sqrt[3]{\bar{z}}>0$ が示された.

(証明終り) 